Вахрамеєва Г.В.

\title{
КУЛЬТ ДЕМЕТРИ В ОКРЕМИХ МІСТАХ І ПОСЕЛЕННЯХ БОСПОРУ В АРХАЇЧНИЙ ЧАС
}

Peферат: У статті розглянуто культ Деметри на Боспорі у VI-V cm. до н.е. У ией період були засновані основні боспорські святилища на честь богині землеробства. Розкопки міст та поселень Боспору дають матеріали, що підтверджують шанування Деметри як у родинному колі так $i$ входження ї̈ у полісний пантеон. Пріоритет античних норм і традицій у культі Деметри зберігався протягом зазначеного періоду.

Ключові слова: Деметра, Кора-Персефона, VI-V cm. до н.е., Боспор, сакральне життя, святилище, теракоти, епіграфічні джерела, елевсінський культ, землеробсько-хтонічний характер культу

Перший період в історії розвитку культу Деметри на Боспорі нерозривно пов’язаний $з$ процесом колонізації Північного Причорномор'я. Від самого початку виникнення боспорських полісів основою їх економіки ставало землеробство. Це підтверджується тим фактом, що сільські поселення виникали разом з містом, навколо якого вони розміщались. Прикладом цьому може слугувати заснування поселення Героївка-5, яке збігається з появою Німфея, або поселення біля міста Кіммерік та багато інших [Кругликова 1975, с. 27-30]. Іншим аргументом є відкриття під час розкопок чималої кількості зернових ям. Так, у Гермонасі було розкопано зернову яма з пшеницею та ячменем [Крижицький та ін. 1998, с. 259].

Закономірно, що в поселеннях Боспору, основою життя яких було сільське господарство, були широко розповсюджені землеробські культи. Особливістю релігійного життя колоній є те, що вірування не зародились на місці нових поселень, а були перенесені 3 метрополії як стійка злагоджена система світогляду. Для того часу давньогрецькому суспільству був притаманний міфологічний світогляд, але в ньому вже почався процес розпаду. 3 великою грецькою колонізацією збігається зародження філософії та становлення етнічної самосвідомості. У VIII-VII ст. до н.е. сталося переосмислення міфології та іï систематизація Гомером та Гесіодом, сформоване цілісне уявлення про богів, їхні епітети та функції [Русяева 1990, с. 80; Крижицький та ін. 1998, с. 265; Русяева 1979, с. 37 ].

Міфологічна традиція зображує Деметру як мати в скорботі. Більшість міфів пов'язані зі стражданнями богині та пошуком дочки. В них відбилися уявлення про явища природи, землеробство. Особливість грецької міфології, в якої архаїчні та класичні сюжети тісно взаємодіяли одне з одним, зумовила наявність хтонічних рис у Деметри та їі тісний зв'язок 3 іншими божествами, які відносились до землеробських культів.

Культ Деметри набув неабиякого поширення як у балканській, так і малоазійській Греції. Це було зумовлене початковим землеробським характером іонійських поселень. Греки переселилися сюди з Аттики вже після падіння Трої (Her. I, 146). До Малої Азії, згідно Геродоту (IX, 97) та Страбону (XIV, 1,3), були перенесені культ і святині Деметри Елевсінської. Вважається, що сам культ елевсінських богинь виник десь у середині XV ст. до н.е., що підтверджується літературними джерелами: «Царем Афинстал Пандион, при котором в Аттику прибыли Деметра и Дионис. Деметру радушно принял в Элевсине Келей» (Apoll. III, 14,7) [Русяева 1979, с. 107-108].

За Геродотом, іонійцями в Мілеті та Ефесі були засновані святилища Деметри Елевсінської [Скржинская 2009, с. 103; Русяева 1990, с. 104]: «Прибыли в область Гесона и Сколопоента, где стоит святилище Деметры Элевсинской...» (Her., IX, 97). А.С. Русяєва вважає, що цей храм став прикладом для колоністів і подібні до нього святилища вони засновували вже на новій батьківщині [Русяева 1979, с. 108].

Таким чином, коріння боспорського культу сягають Аттики, де знаходилось головне в усьому античному світі святилище Деметри. Це дає можливість припустити, що боспорським 
колоністам був знайомий саме елевсінський культ. До цієї думки схиляються С.Ю. Саприкін i А.С. Русяєва, які присвятили культу Деметри на Боспорі грунтовні статті [Сапрыкин 1983; Русяева 2009].

Загалом питання боспорських культів зазвичай розглядаються у зв'язку з відкриттям та публікацією сакральних комплексів або культових предметів. Постійне накопичення археологічних матеріалів, пов'язаних з сакральним життям населення Боспорського царства, слугувало поштовхом для визначення питань сакрального життя, як одних 3 найбільш актуальних та пріоритетних напрямів сучасного антикознавства.

Історіографію проблеми культу Деметри в сакральному житті населення Боспорської держави можна поділити на такі групи:

1. Узагальнюючі праці, в яких $\epsilon$ коротка характеристика релігійного життя на Боспорі та, власне, й культу Деметри (В.Ф. Гайдукевич, В.Д. Блаватський).

2. Праці, присвячені релігії Північного Причорномор'я та Боспору (А.С. Русяєва, М.В. Скржінская, С.Ю. Саприкін).

3. Дослідження культів і сакральних комплексів окремих поселень (М.М. Кобиліна, В.Ф. Гайдукевич, Д.Є. Чистов, Н.В. Молева, Є.А. Молев, І.Д. Марченко, А.А. Завойкіна та інші).

4. Праці, присвячені вивченню та публікації окремих видів джерел з цього питання: теракот, графіті, епіграфічних написів тощо (М.М. Кобиліна, В.І. Денисова, А.С. Русяєва, Т.А. Ільїна, С.А. Молев, Н.В. Молева, Л.Г. Шепко, М.Ю. Вахтіна, О.В. Горська та інші).

Треба зазначити, що, попри активне вивчення проблем культу елевсінських богинь на Боспорі, зазначена проблема майже не знайшла комплексного висвітлення в науковій літературі, а відтак потребує подальшого розгляду, зокрема й через зростання матеріалів розкопок.

Метою даної роботи $є$ загальний огляд культу Деметри в сакральному житті мешканців Боспору у архаїчний період (VI-V ст. до н.е.).

Перш, ніж перейти до розгляду пам'яток, що мають безпосереднє відношення до боспорського культу Деметри, слід пояснити логіку викладення матеріалу. Культові знахідки умовно можна поділити на три групи: 1) громадські сакральні комплекси; 2) речі, що були знайдені при розкопках поселень; 3) матеріали некрополів.

Хронологічно до найдавніших відносяться знахідки зі міських та сільських поселень Боспору. Відтак саме з цього комплексу автором вирішено почати огляд культу богині родючості. Крім того, у більшості випадків дослідники розглядають джерела, що їх знайдено поза межами великих сакральних споруд, як допоміжний матеріал в ілюстрації масовості культу. Але, крім цього, вони є свідченням родинних культів. Релігії родини довгий час в історіографії не приділяли належної уваги, а тому виділення ії проявів у окрему групу $\epsilon$ актуальним.

В межах другої групи розглянемо храмові громадські споруди у містах та поза ними. Вони свідчать водночас про полісний та родинний культ, адже ці дві сторони релігії тісно пов'язані між собою. Ця група є важливою, адже, спираючись на їі матеріали, можна робити висновки щодо державного характеру того чи іншого культу.

Окремою групою виступають речі, знайдені у некрополі, оскільки вони мають відношення до поховального культу.

Найбільш ранні археологічні знахідки, що підтверджують шанування Деметри та іiі дочки, датуються початком VI ст. до н.е. і відносяться до проявів родинного культу. Так, в архаїчному будинку Тірітаки були знайдені родоські статуетки богині, яка сидить на троні. Вона одягнена в довгий хітон, на голову накинуте покривало, що спускається на плечі, поверх покривала - високий головний убір. Руки щільно притиснуті до тіла, пальці показані перебільшено-подовженими. Обличчя виконане в типовому для архаїки стилі: архаїчна посмішка, опуклі очі без вік. Трон не прикрашено, має високу спинку. Теракота була розписана, але розпис зберігся лише на лавочці спереду у вигляді ряду вертикальних смуг, 
виконаних червоною фарбою. Поруч з ними також було знайдено фігурку дівчини, яка стоїть. У цьому контексті богиню на троні можна трактувати як Деметру, а дівчину - як Кору-Персефону. [Кобылина 1961, с. 27; Гайдукевич 1940, с. 300-317; Денисова 1981, с. 125, табл. 1, б, г; Пругло 1970, с. 90].

Інтерпретація типу богиня на троні є дискусійною. Статуетки не мають атрибутів, які б дозволили точно встановити, якій богині вони належать. Саме тому в античній історіографії за цим типом закріпилася назва «богиня на троні» або «богиня, що сидить», а не Деметра чи Гера, Афіна, Кібела та інші богині, до яких відносять ці статуетки.

Проте більшість таких статуеток було знайдено під час розкопок храмів Деметри та Кори-Персефони, зокрема в Елевсіні - головному святилищу Деметри та Кори-Персефони. Це дає можливість віднести боспорські зображення богині, що сидить, до культу Деметри [Русяева 1982, с. 34; Кобылина 1961 с. 29]. Так само їх інтерпретують і дослідники теракот Давньої Греції. Одним з багатьох прикладів може слугувати робота Г. Меркер, що вивчала теракоти Корінфа [Merker 2000, p. 42-45]. На думку А.С. Русяєвої, відсутність атрибутів свідчить про те, що образ Деметри був широко відомим по всій грецькій ойкумені та був зрозумілим без додаткових символів [Русяева 1982, с. 35].

Велику кількість статуеток i протом Деметри було знайдено під час розкопок Фанагорії. Найбільше теракот богині землеробства було відкрито у Східному кварталі. Фанагорійські теракоти, як і інші боспорські вироби коропластики, знайдені у цій період, відносяться до типу «богиня на троні» та до іонійського i родоського типу протом 3 характерною архаїчною посмішкою [Кобылина 1956, с. 16].

Цікавим є те, що майже від кінця VI - початку V ст. до н.е. місцеві коропласти почали виготовляти власні вироби, які за іконографічним типом не мають відмінностей від своїх імпортних аналогів [Кобылина 1974б, с. 20]. Ранні зразки представлені протомою, яка типологічно відповідає іонійському варіанту архаїчних протом-бюстів та статуеткою Деметри на троні. Але, на відміну від привезених теракот, вони не оброблені стеком, відтак усі деталі обличчя та фігури є нерельєфними і нечіткими. М.М. Кобиліна вважає, що вони були виготовлені в іонійських матрицях іонійськими майстрами, які переселилися на Боспор [Кобылина 1956, с. 18]. Але виникає питання: якщо це були малоазійські майстри, то чому вони не обробляли свої вироби стеком. Враховуючи низьку якість обробки теракот, можна припустити, що над ними працював майстер без досвіду роботи 3 коропластикою, або ці теракоти виготовлялись як дешеві аналоги імпортних теракот і тому не потребували додаткової обробки, яка підвищувала їх собівартість.

Втім серед місцевих виробів були теракоти, якість яких наближалася до імпортних. Так, деякі протоми богині з Гермонаси були оброблені стеком і за зовнішніми ознаками відповідають своїм імпортним аналогам. Цікаво, що глина, з якої вони виготовлені, $\epsilon$ фанагоріїською, тому можна припустити, що і виготовлені вони були у майстернях Фанагорії [Коровина 1974, с. 40 табл. 46, 1, 3].

Майстерні коропластів виникли не лише у Фанагорії, але й Пантікапеї. У 1962 р. на горі Мітрідат було відкрите приміщення майстерні кінця VI - початку V ст. до н.е. Тут було знайдено піч для випалювання, рештки керамічного виробництва та чимало бракованих теракот. Частина знайдених статуеток оброблялись стеком, деякі з них мають ліпні деталі. Типологічно вони є аналогічними родоським та самоським [Кобылина 1974, с. 47]. Серед них відомі фрагменти статуетки богині на троні, деталі одягу або обличчя якої є нечіткими. Відносяться знахідки до другої половини VI ст. до н.е. [Кобылина 1974, с. 50 табл. 58, 1-2].

Серед місцевих теракот архаїчного часу привертає увагу протома 3 Гермонаси, яка зображує богиню $з$ квіткою в руці й датується V ст. до н.е. Попри те, що протому було знайдено в морі, а сама вона $\epsilon$ сильно пошкодженою і фрагментованою, на ній можна побачити сліди обробки стеком. А.К. Коровіна інтерпретувала її як Деметру [Коровина 1974, c. 40, табл. 46, 3]. Але, на нашу думку, наявність у руці богині квітки вказує на те, що це 
Кора-Персефона, адже тут можна побачити алегорію міфу про викрадення Кори-Персефони Аїдом, яка в момент викрадення збирала квіти у лузі:

$$
\begin{aligned}
& \text { «В сонме подруг полногрудых, рожденных седым Океаном, } \\
& \text { Дева играла на мягком лугу и иветь собирала... } \\
& \text { Иуж сорвать собиралась, как вдруг раскололась широко } \\
& \text { Почва Нисийской равнины, и прянул на конях бессмертных } \\
& \text { Гостеприимец-владыкка, сын Кроноса многоименный. } \\
& \text { Деву насильно схватив, он ее в золотой колеснице } \\
& \text { Быстро помчал...» }
\end{aligned}
$$

(Hom. Hymn. V 1-2, 16-20).

Крім того, квітка в руці може бути символом весни, яку втілює в собі Кора-Персефона [Русяева 1982, с. 36].

Привертають увагу родоські статуетки богині на троні, Кори, протоми Деметри, які відносяться до VI ст. до н.е. і були відкриті В.Ф. Гайдукевичем 1938 р. на Тірітаці у приміщенні А. Окрім родоських, тут було знайдено статуетку з Аттики: богиня одягнена в хітон, гіматій, на голові - стефана; трон у верхній частині спинки прикрашено напівкруглими виступами [Пругло 1970, с. 93, табл. 35, 3; Гайдукевич, 1952, с. 93, рис. 94; Денисова 1981, с. 125 табл. 1, в].

Малоазійські статуетки богині на троні були знайдені при розкопках Кіммеріка [Кругликова 1970, с. 83]. У матеріалах з Фанагорії представлено статуетку типу «богиня на троні» з Мілету - метрополії Боспору: богиня сидить, поклавши руки на коліна; одежу і трон показано схематично, без виділення деталей [Кобылина 1956, с. 16; Winter 1903, tab. 43, 1-5].

Також серед ранніх статуеток цікавою є фігура богині, яка сидить на троні з високою спинкою, з Порфмія: вона одягнена в хітон, руки і ноги не змодельовані, має пишну зачіску [Вахтина 2010, с. 233-24].

Архаїчні теракоти Деметри знаходили майже в усіх боспорських містах. Вони мали спільні іконографічні риси, більшість 3 них є привозними. Здебільшого вони мають родоське походження, дещо менше - іонійських. Від середини V ст. до н.е. збільшується кількість афінських виробів і вони починають заміщувати іншу імпортну коропластику. Загалом імпортні вироби за своїм походженням відповідають тим регіонам, 3 яким у Боспора існували торгові зв'язки: Родос, Мілет, Самос, Корінф, Афіни.

Знахідки статуеток у будинках дозволяють зробити висновок про існування в них домашніх святилищ [Шевченко 2008, с. 114]. Н.В. Молева відносить такий тип культових споруд до самого давнього на теренах Боспорської держави. Вони з'являються в першій половині VI ст. до н.е. в таких новостворених боспорських містах, як Пантікапей, Фанагорія, Тірітака, Мірмекій тощо. Для домашнього святилища характерним є просте планування, знахідки вотивних приношень. Іноді в центрі розміщують відкрите вогнище, ще рідше вівтар [Молева 2001, с. 131-132]. Прикладом використання домашнього вогнища в якості вівтаря можуть слугувати знайдені при розкопках 2007-2010 рр. в Тірітаці статуетки богині на троні в розвалі домашньої печі [Зинько 2007, с. 43].

Стосовно релігійного світогляду сільського населення Боспору можна сказати, що 3 моменту заснування поселення серед знахідок трапляються теракоти, які зображують Деметру чи Кору, або відносяться до землеробської релігії. Як і в містах, саме теракоти $\epsilon$ головним джерелом для вивчення сільського культу Деметри. Щоправда для поселень хори в багатьох випадках вони стають єдиним джерелом, яке свідчить про шанування богині землеробства. Сакральні пам'ятки хори Боспору VI-V ст. до н.е. можна віднести до проявів родинного культу, адже знаходили їх у приватних будинках і садибах. Так, при розкопках Героївки, Південно-Чурубашського поселення та інших було відкрито зольники, фрагменти виробів коропластів, значна частина яких належить протомам і статуеткам богині Деметри. Трапляються типи «богиня на троні» та «богиня з руками на грудях», аналогії яким можна 
виявити в інших подібних поселеннях i містах Боспору [Сапрыкин 1983, с. 62-63]. Прикладом ранніх теракот може слугувати фрагмент статуетки богині, що сидить 3 поселення Героївка-1, яке датується останньою чвертю VI ст. до н.е. [Зинько 2007, с. 223].

Теракоти VI ст. до н.е. траплялись і при розкопках азійського Боспору. Статуетку типу «богиня на троні» було знайдено В.Д. Блаватським у 1954 р. при розкопках поселення Западно-Зеленське [Блаватский 1962, с. 5]. Цікавий екземпляр теракоти Деметра на троні першої половини V ст. до н.е. походить зі Семібратного городища: на голові калаф та покривало, риси обличчя масивні; трон 3 виступами 3 обох боків; виготовлена 3 фанагорійської глини, оброблена стеком [Кобылина 1974а, с. 43 табл. 49, 4].

Виразних відмінностей між міськими та сільськими сакральними місцями немає. Головною проблемою вивчення культу Деметри на хорі стає гірше збереження пам'яток, порівняно 3 містами. Крім того, сільська територія Боспору досить пізно почала вивчатися, особливо в релігійному аспекті.

Отже, аналізуючи матеріали поселень, можна зробити висновки, що більшість проявів культу богині родючості, як у містах, так і у сільських поселеннях, відносяться до родинних культів. До нас дійшли теракоти Деметри та їі дочки Кори-Персефони, а також поодинокі залишки домашніх вівтарів. Вони з'являються одночасно заснуванню поселень. Крім домашніх святилищ, теракоти знаходили при розкопках майстерень коропластів. Все це разом засвідчує широку популярність культу Деметри серед населення Боспору.

Громадські культові споруди виникають майже одночасно з домашніми святилищами. Їх дещо пізніша поява видається цілком логічною, адже на будівництво храмового комплексу потрібно більше часу та витрат, ніж на спорудження домашнього святилища. Заснування святилища було важливою справою для греків і тому будівництво сакрального комплексу починалось одночасно 3 будинками, укріпленнями та іншим необхідним для життя спорудами [Скржинская 2004, с. 91].

У першій половині VI ст. до н.е. виникає святилище Деметри в Німфеї, яке знаходилося на прибережній гряді, за трьома скелями. Воно було розкопане В.Ф. Гайдукевичем у 30-40-х роках XX ст. і являло собою невелике приміщення площею 10 кв. м. Біля однієї зі стін знаходилась розщелина. Будівля мала дерев'яне перекриття, поверх якого лежала черепиця. Вхід було прикрашено карнизом, який складався 3 теракотових плиток $з$ геометричним розписом у вигляді двох трикутників. Всередині будівлі знайдено багато уламків 3 сірої глини. Цей храм цікавий і тим, що від моменту його спорудження там існували гончарні печі для випалювання керамічних виробів і теракот. Кількість знайдених біля печей керамічних уламків свідчить про те, що вони використовувались не тільки для потреб святилища [Соколова 2004; Ohlerich 2011, s. 110-111, 113]. Топографія святилища є дуже показовою, адже вона $\epsilon$ характерною саме для сакральних комплексів Деметри Елевсінської, які облаштовували серед скель та розщелин.

При розкопках німфейского святилища було знайдено значну кількість протом i статуеток Деметри. За іконографічним типом вони є подібними до теракот домашніх святилищ, описаних вище. Примітним можна вважати той факт, що, окрім імпортних творів коропластів, було знайдено місцеві. Найбільш ранні з них відносяться до кінця VI ст. до н.е. Наприклад, це статуетки богині, що сидить на троні. Місцеві теракоти виготовлено 3 коричневої пористої глини [Сапрыкин 1983, с. 61-62, 85-86]. За іконографічним типом вони збігаються з імпортними теракотами. Більшість з них схожі з родоськими теракотами. Вони закутані у покривало, одежа зливається з троном. Сам трон зображується як з виступами, так i без них [Скуднова 1970, с. 85, табл. 28, 2-4, 7]. Отже, можна припустити, що матриці виготовлялись місцевими майстрами за привізними теракотами. Подібність місцевих виробів до родоських, вочевидь, зумовлена поширенням тут глиняних статуеток з Родосу та тісними торговими зв'язками з цим регіоном.

Окрім статуеток богині на троні та Кори, було знайдено фігурку бога, що лежить 3 ритоном у руці. Аналогічна картина спостерігалась при розкопках однієї могили в 
Пантікапеї. С.Ю. Саприкін, наводячи аналогії з розписами загробних трапез, де також зображували бога, що лежить, трактує цю статуетку, як хтонічного Діоніса або Аїда [Сапрыкин 1983, с. 63].

Цікавими є теракотові маски зі зображенням сатирів і Деметри. Подібні маски знаходили при розкопках самоського некрополя і Спарти. Ритуал з використанням маски в одному зі святилищ Аркадії описує Павсаній. Жрець одягав маску Деметри та бив жезлом по землі, імітуючи гнів Деметри на підземних богів: «в ней хранится маска Деметры Кидарии (со священной повязкой). Надев на себя эту маску во время так называемых Больших мистерий, жрец поражает подземных демонов, ударяя в землю жезлом» (Paus VIII.15.3). Аналогічний ритуал могли проводити i в німфейському святилищі [Античная мифология 2004, с. 437; Ohlerich 2011, s. 111; Русяева 2009, с. 112]. Німецький дослідник I. Олеріч не виключає, що гіпотетично могли провадитись обряди, схожі на описані Павсанієм в Аркадії, але вважає, що насамперед німфейські маски могли слугувати ідентифікацією вівтаря [Ohlerich 2011, s. 113]. Заперечує відношення цих масок до культу Деметри російський дослідник І.Ю. Шауб. Виступаючи з різкою критикою А.С. Русяєвої та М.М. Худяка, він наполягає на тому, що ці маски мали відношення до кола культів Діоніса або німф [Шауб 2008, с. 295-296]. Натомість критик не наводить переконливих аргументів на свою користь. Щодо відношення цих масок до культу Діоніса, можна зазначити, що культи Діоніса та Деметри були тісно переплетені, а в елевсінських містеріях ці божества разом 3 Корою-Персефоною були головними персонажами. Слід визнати, що фрагментарність масок, дійсно, ускладнює їх інтерпретацію, тому як припущення А.С. Русяєвої, так і І.Ю. Шауба, мають право на існування. Але загальний контекст знахідок святилища, більше натякає на їх відношення до кола Елевсінських богинь.

Крім теракот, при розкопках Німфею було виявлено чимало присвятних графіті. Більшість 3 них нанесено на денце посудин і представлено лігатурами $\Delta \mathrm{i} \Delta \mathrm{H}$. Таке розміщення напису, на думку О.В. Горської, може говорити про хтонічний характер присвят Деметрі [Горская 2002, с. 116].

Наприкінці VI ст. до н.е. храм гине від пожежі. Значення німфейського сакрального комплексу для дослідження культу Деметри полягає в тім, що він демонструє нам найдавніші громадські ритуали, пов'язані з землеробською релігією, адже на сьогодні це найстаріше 3 відомих міських святилищ Боспору. В ньому чітко простежуються землеробсько-хтонічні риси культу Деметри, схожість 3 елевсінськими ритуалами, що дозволяє припускати знайомство боспорського населення добре знало Гомеровський гімн «До Деметри» та ритуали елевсінського культу.

На межі VI-V ст. до н.е. з'являються сакральні комплекси на Фонталовскому півострові (Берегове-4), в Мірмекії та Фанагорії. Сакральний комплекс в Мірмекії можна віднести до великих боспорських святилищ, його розміри сягали 400 кв. м. Воно також було відкрите В.Ф. Гайдукевичем. У другій чверті V ст. до н.е. воно було зруйноване, проте в середині століття відбудоване заново. Значні розміри комплексу, наявність вівтаря, а також особливе ставлення до цього місця (споруда зольників і нового святилища), дозволяють припускати, що ми маємо справу з однією з найбільш ранніх громадських будівель у місті [Чистов 2006, c. 99-133]. Але розквіт діяльності цього комплексу припав на IV ст. до н.е., тому детальніше ми його розглянемо у наступному розділі, який присвячено класичному періоду.

Серед коропластики Мірмекія, яка за своїм іконографічним типами не відрізнялась від теракот, знайдених у інших містах, можна виділити архаїчну іонійську теракоту богині на троні з буквою $\Delta$ на підставці, яка дослідниками трактується як скорочення імені богині. На жаль, збереглася лише нижня частина статуетки: на уламку є біла обмазка і сліди червоної фарби; права рука богині покладена на коліна, а в лівій, мабуть, був якийсь предмет [Наливкина 1952, с. 330; Сапрыкин 1983, с. 61].

Храмовий комплекс у Фанагорії виник майже водночас з появою міста. Але знаходився він поза стінами поселення, за кілометр на південь від городища [Долгоруков 1984, с. 78]. 
Більш відомий цей комплекс як святилище Майська гора (Блевака). Ю.М. Кузьміна у своїй дисертації, присвяченій аналізу святилищ Азійського Боспору, віднесла цей храм до приміських святилищ. Сакральний комплекс Майська гора містився на грязьовому вулкані. 3 огляду на це, можна зробити висновок, що святиня мала безпосереднє відношення до хтонічних культів, адже жерла вулканів греками розглядалися в якості входу до підземного світу [Завойкин 2006, с. 70]. І.Д. Марченко пов'язує таке розміщення саме 3 догрецькими віруваннями, які існували до розпаду абстрактної Богині-Матері на конкретні божества [Марченко 1974, с. 31-32]. Навколо сакрального комплексу було облаштовано некрополь.

Розкопки на цій пам'ятці проводились від XIX ст. Неабиякий внесок у вивчення цієї пам'ятки у післявоєнні часи зробили М.М. Кобиліна та І.Д. Марченко. Тут було знайдено будівлю антового типу із сирцевими стінами, планування і розмір якої $\left(10 \mathrm{~m}^{2}\right)$, дозволили І.Д. Марченко віднести іï до храму. Будівля мала карниз, розписаний геометричним візерунком, і акротерії зі зображенням квітів лотоса. Наприкінці VI ст. тут сталася пожежа, про що свідчать горілий грунт i рештки сажі на черепиці [Ильина 2008, с. 21; Долгоруков 1984, с. 65].

Південніше першої будівлі була відкрита природна розколина довжиною $12 \mathrm{~m} \mathrm{i}$ глибиною 2,2 м. Її заповнення складається 3 великої кількості сильно фрагментованих протом жіночих божеств (Деметри, Кори, Афродіти, Артеміди) та карибів, які датуються від VI до III ст. до н.е. Загалом відкрито 1164 зразки протом, представлених цілими i фрагментованими теракотами. Разом з протомами тут трапляються і об'ємні статуетки. До найбільш ранніх статуеток відносяться родоські фігури богині, що сидить у кріслі 3 виступами у верхній частині спинки [Ильина 2008, с. 24]. Також знайдено чимало архаїчних статуеток з місцевої фанагорійської глини. За типом вони схожі на імпортні родоські. Пізніше, у V ст. до н.е. 3'явились вироби, виготовлені за беотійськими та аттичними матрицями [Марченко 1974, с. 31-32]. Значна кількість теракот із місцевої глини пояснюється тим, що на території сакрального комплексу було налагоджене керамічне виробництво. Неподалік від розколини було знайдено гончарну піч, а також матриці для виготовлення протом і статуеток [Долгоруков 1984 с. 64-65].

Найбільше у розколині було знайдено протом Деметри та Кори-Персефони: на голові у богині - калаф, покривало покриває всю фігуру; у деяких варіантах зображено волосся i сережки у вухах. Трапляються як протоми-бюсти, так i протоми-півфігури. Багато зі знайдених виробів належать до одного виду. Так, було знайдено 200 екземплярів ідентичних протом-бюстів у калафі та покривалі, складки якого звисають обабіч шиї: самі зображення стилізовані, без деталей та додаткової обробки стеком [Марченко 1974, с. 33, табл. 37, 1]. Серед знахідок у заповнені трапляються протоми богині з руками на грудях: на голові у Деметри також калаф, покривало закриває майже всю фігуру; волосся - у вигляді об'ємного наліпа, у вухах - сережки [Марченко 1974, с. 33 табл. 37, 4].

Цікавою є парна статуетка двох жінок, що цілуються - можливо Деметри та Кори. Деметру зображено в тонкому іонійському хітоні, складки якого видно на спині богині; правою рукою вона обіймає юну Кору, що припала до іiі грудей, а лівою притримує покривало; виготовлено з фанагорійської глини в однобічній формі [Ильина 2008, с. 24 Марченко 1974, с. 35 табл. 40.3]. І. Д. Марченко наводить аналогію з родоською стелою зі схожим сюжетом і вважає, що це зображення ілюструє зустріч матері 3 дочкою [Марченко 1974, с. 32; Ильина 2008, с. 25].

Дослідниця цього комплексу І.Д. Марченко вважає, що причиною заповнення розщелини теракотами стала заміна їх у храмі новими. Культове значення цих предметів не дозволяло їх просто викинути на смітник, тому їх скинули у розщелину на території сакрального комплексу [Марченко 1962 с. 122]. Т.А. Ільїна ставить під сумнів твердження I.Д. Марченко і пов'язує наповнення розщелини безпосередньо з культовою практикою [Ильина 2008, с. 32]. Загалом, наявність в ущелині такої кількості протом і статуеток Деметри й Кори, а також кісток тварин, зокрема свиней, дозволяє припустити, що тут 
провадилися обряди, пов'язані з хтонічною іпостассю Матері й Доньки, що мають аналоги в Кітеї, Німфеї, Береговом-4 і т.п.

До V ст. до н.е. належать знайдені кіліки з графіті К і КО. Подібне гравірування, яке представлене літерами $\Delta \mathrm{K} \mathrm{H}$, трапляється на протомі богині $з$ цього ж комплексу [Ильина 2008, с. 29]. Такі графіті могли бути скороченням імені богині Кори.

Крім теракот, що їх можна тлумачити як Деметру чи Кору, тут були знайдені протоми Афродіти. Культи Афродіти та Деметри на Боспорі були дуже близькими. Це пов'язано 3 тим, що ці культи розвивались від одного первісного жіночого божества, а також тим, що Афродіта на Боспорі зберегла свої хтонічні риси. Сили природи ототожнювались не тільки 3 Деметрою і Корою, але і з Герою, Артемідою, Афродітою [Бунин 2005, с. 19-20].

Загалом знахідки теракот певного божества в храмі іншого не $є$ рідкістю для античних святилищ. Давньогрецька релігія не мала строгих канонів, функції богів могли поєднуватись. В одному сакральному комплексі могли існувати місця шанування інших богів. Скоріш за все, так було і у святилищі Майська гора. Окрім теракот, на це вказують знайдені тут залишки рельєфу зі зображенням Афродіти Апатур [Марченко 1977, с. 122-124].

Таким чином, матеріали святилища Майська гора свідчать про те, що на ньому 3 моменту заснування проводились ритуали, пов'язані з землеробськими культами, насамперед 3 Деметрою і Корою, а також іншими жіночими божествами та карибами.

Схожі риси за місцеперебуванням, характером культових дій мав сакральний комплекс Берегове-4, який також облаштували на мисі біля підніжжя грязьового вулкана, що вказує на зв'язок цього місця зі хтонічними богами, адже елліни вважили, що вулкани є входами до підземного світу [Завойкин 2006, с. 61-62]. Безпосередньо зі схилів вулкана стікали потоки води. Вода грала велике значення в елевсінському культі. В останній день Великих елевсінських містерій відбувалося так зване «узливання достатку» в ущелини [Завойкин 2006, с. 70]. Наявність вулкана і джерел вод дозволяє припустити, що подібні обряди могли проводитися і тут.

Також біля святилища були відкриті невеликі ями, заповненні вугіллям і золою, в яких спалювали у великій кількості дерево. На думку О.А. Завойкіна, вони мали ритуальне значення, будучи вогняними есхарами, що являли собою символи полум'я підземного царства Аїда, чоловіка Кори-Персефони. Сама Персефона асоціювалася у греків 3 вогнем. В Елевсінських містеріях вогонь відігравав важливу роль, він майже всюди супроводжував містів. Під вогнем їм відкривалися священні таїнства [Завойкин 2006, с. 71]. Показово, що при розкопках не було знайдено решток господарчої діяльності. Отже, всі виявлені тут артефакти мали сакральне призначення.

Ю.Н. Кузьміна у своїй дисертації віднесла Берегове-4 до сільських святилищ [Кузьмина 2011, с. 13]. На нашу думку, таке визначення обмежує значення цього комплексу. Відомо, що святилища Деметри найчастіше засновували поза межами міст, на мисах, висотах, узбережжі, біля скель [Русяева 2009, с. 103]. Відтак, це були полісні святилища, де під час свят могли збиратися мешканці міст і хори. На користь такого тлумачення можуть слугувати й масштаби комплексу.

Дослідник цього комплексу, О.А. Завойкін, неодноразово підкреслював, що Берегове-4 - це святилище Елевсінських богинь. Він підтверджує це як знахідками, так і локалізацією, а також характером святилища, яке нагадує відомі святилища Деметри, наприклад у Мілеті метрополії Боспору. Деякі схожі риси воно має і з сакральним комплексом в Елевсині [Завойкин 2006, с. 73]. Таким чином, ми маємо справу з унікальною пам'яткою, яка засвідчує знання і практику мешканцями Боспору елевсінського культу.

Як і в інших храмах Боспору тут було знайдено багато теракот Деметри та ï дочки Кори-Персефони. Серед них найбільш цікавою є знахідка - стоячої парної статуетки, повна аналогія знайденої на Східному некрополі Фанагорії кінця V ст. до н.е. Крім того, була знайдена парна статуетка сидячих богинь - Деметра в калафі та Кора в покривалі 
[Завойкин 2002, с. 262]. Парні статуетки символізували єдність матері та дочки, а також мали безпосереднє відношення до культу елевсінських богинь.

До другої половини VI ст. до н.е. відноситься святилище поблизу Тірітаки. При його розкопках були знайдені протоми Деметри, які й дозволили зробити припущення, що там проводились обряди на честь Деметри [Пругло 1970, с. 94, табл. 38, 1].

До того ж часу належить храм хтонічних божеств у Фанагорії, який проіснував до початку V ст. до н.е. Тут було знайдено акротерії, як у святилищі Майська гора. Теракот Деметри або Кори тут не виявлено, але, враховуючи їх відношення до хтонічних божеств, можна припустити, що тут могли поклонятися богиням у їх хтонічній іпостасі [Долгоруков 1984, с. 65].

Важливим відкриттям став храм Деметри VI ст. до н.е., який було розкопано 2010 p. поблизу хутора Вісник спільною археологічною експедицією IA PAH, Південо-Російського Центру археологічних досліджень (Краснодар) та IIMК РАН (СПб). Площа відкритої споруди близько $200 \mathrm{~m}^{2}$. Ймовірно, вона мала 4 колони. У центрі найбільшого приміщення розташовувався вівтар. Дах було покрито черепицею лаконського типу, виробництва Горгіпії. Основні знахідки - теракоти, фрагменти черепиці, амфор і кістки тварин [Чевелев 2011, с. 403, 411].

У першій чверті V ст. до н.е. Боспорська держава вийшла на новий етап свого розвитку. В той час мешканцям Боспору почали загрожувати скіфи. Це привело до втрати сільських територій та економічних труднощів. Але, з іншого боку, нові обставини стали передумовою консолідації окремих полісів у складі єдиної держави під егідою Архенактидів [Крижицький та ін. 1998, с. 272].

Відомо, що до складу Боспорської держави зі столицею у Пантікапеї на той час уже входили Тірітака, Мірмекій, Порфмій, Фанагорія, Гермонасса та Кепи [Крижицький та ін. 1998, с. 274].

У 438 р. до н.е. до влади прийшла нова династія - Спартокідів. Як саме відбувся перехід від однієї династії до іншої античні автори не повідомляли. А.С. Русяєва і В.М. Зубарь вважають, що Спартак походив $з$ малоазійського царського роду та був одружений з дочкою останнього Архенактіда, який не мав синів. Тому на Боспорі його добре знали, він обіймав високі посади та перехід влади стався без опору [Крижицький та ін. 1998, с. 275-276].

В цей період починає зростати роль Афін у житті Боспорського царства. М.В. Скржинська, спираючись на дані афінського декрету 418 р. до н.е. (в якому афіняни закликали своїх союзників відсилати десятину до Елевсіну), вважає, що, починаючи від першої третини V ст. до н.е., можна говорити про зв'язок Боспора з Елевсіном [Скржинская 2009, c. 84]. Однак цей декрет говорить скоріше про зміцнення зв'язків з Афінами, ніж про знайомство з елевсінським культом мешканцями Боспору, адже у метрополії Боспору - Мілеті - шанували саме цей культ, і у такому вигляді його було перенесено на нову батьківщину, про що свідчать ранні археологічні пам'ятки Боспору, про які йшлося вище. Але, безумовно, цей декрет говорить про вихід цих зв'язків на якісно новий рівень. I це, на думку А.С. Русяєвої, призвело до змін у культі богині родючості [Русяева 1979, с. 37].

Виникнення святилищ Деметри в Пантікапеї, Кітеї, Феодосії відноситься саме до другої половини V ст. до н.е. [Завойкин 2006, с. 70; Бутягин 2004, с. 48-53; Долгоруков 1984, с. 31; Молев 2003, с. 253; Петрова 2001, с. 233].

Н.В. Молєва, аналізуючи архаїчні сакральні пам'ятки Боспору, вважає, що пантікапейський храм мав елементи дорійського та іонічного орденів [Молева 2002, с. 133]. Але це може бути тільки припущенням, адже сам храм не знайдено. А до нашого часу дійшла лише кругла мармурова база вівтаря, знайдена у підошви гори Мітрідат. Неглибоким рельєфом по всьому колу циліндра і на всю його висоту зображено жінок з факелами, закутаних в гіматії [Скржинская 2009, с.97-98]. Підтвердженням існування святилища у Пантікапеї є також вотивний рельєф кінця V ст. до н.е. із зображенням цієї богині разом 3 дочкою Корою. Кора-Персефона тримає у своїй руці факел. Такі зображення Персефони, 
Деметри, Іакха та учасників містерії з факелами трапляються як в Елевсіні, так і по всій материковій Греції. Світло факела в темряві символізувало щасливе потойбічне життя. Персефона вважалася богинею вогню, а сам вогонь грав важливу роль у землеробських обрядах. Відомо, що факели використовували не тільки в Елевсінських містеріях, а і в святах на честь Іакха [Журавлев 2004, с. 107-108].

Спорудження святилища у Феодосії, яка на той час ще не входила до складу Боспорської держави, а була самостійним полісом, дослідники відносять також до V ст. до н.е. Храм міг походити по зовнішньому вигляду на монументальний периптер іонічного ордера в Пантікапеї [Петрова 2001 с. 236].

Про шанування Деметри Елевсінськой може свідчити знайдена у Феодосії групова статуетка Деметри Кори та Іакха - так звана елевсінська тріада. Саме в Елевсінських містеріях ці божества виступають разом, а народженню Іакха присвячується окремий день свята, під час якого учасники процесії приносять йому іграшки. Як і Деметра, Іакх-Діоніс був одним із найбільш відомих грецьких богів і відповідав за родючість землі. У міфології існувало багато іпостасей Діоніса. Дві з них були пов'язані з Елевсінськими богинями. Перший - Діоніс-Загрей, син Персефони та Зевса, був вбитий титанами та воскрес. Тобто він, як Кора-Персефона, зійшов у царство мертвих і повернувся на землю у більш високому статусі [Русяева 1979, с. 72]. В Елевсінських містеріях, особливо у V-III ст. до н.е. важливу роль відігравав Діоніс-Іакх син Зевса та Деметри [Русяева 1979, с. 43, 72]. Ніч 320 на 21 боедроміона була присвячена шлюбу Зевса, який асоціювався з небом і дощем, що дає життя землі й Деметрі, а також народженню Іакха [Русяева 1975, с. 64]. Його введення в елевсінські містерії пов'язане з розвитком виноградарства і орфічними вченнями. Деметра, яка дає хліб, i Діоніс-Іакх, який дає вино, стали для еллінів головними землеробськими божествами [Русяева 2005, с. 318].

Цікаво, що поряд з нею було знайдено фігурку Геракла, якого теж було присвячено у таїнства Деметри. Перш, ніж зійти до Аїду для виконання останнього завдання, Геракл вирушив до Елевсіну, де попросив дозволу взяти участь у містеріях. Але, оскільки в часи Геракла до містерій допускалися лише афіняни, Тесей запропонував усиновити Геракла афінянином Пілієм. Але постала ще одна проблема - Геракл перебив кентаврів, а бачити таїнства не могла людина з закривавленими руками. Тоді Деметра вирішила організувати для нього малі містерії для очищення і підготовки до великих містерій [Молева 2002, с. 208; Кобылина 1974, с. 80]. Судячи 3 міфу, знання містерій були потрібні Гераклу для успішного виконання завдання. Йому потрібно було привести з Аїду Цербера, тобто зійти до підземного царства Аіда і повернутись звідти живим, а це могли зробити лише причетні до таємних знань. Отже, ми бачимо, що популярність елевсінських містерій базувалась саме на наданні містам надії на життя після смерті.

Землеробсько-хтонічні ритуали проводились у сакральному комплексі Кітея. Про це свідчать залишки жертвоприношень у розщелинах: теракоти, черепки посуду, графіті на чорнолаковій посудині, кістки тварин (свині, коней, дрібної рогатої худоби), глиняні моделі хліба, світильники. Крім того, саме розтушування святилища у скелях свідчить про його зв'язок з підземним світом [Молева 2002, с. 190]. Наповнення розщелин і характер жертвоприношень дає змогу зробити висновок про проведення тут елевсінських ритуалів. Так, тут були знайдені присвяти Деметрі, Корі та Іакху, які виступали головними фігурами в елевсінських містеріях [Молева 2002, с. 190].

На користь твердження щодо елевсінського характеру обрядів свідчать знахідки світильників [Молева 2002, с. 190]. Адже під час розкопок Елевсіна вчені знаходили поряд 3 теракотами чимало світильників, особливо в шарі кінця VII-VI ст. до н.е. Такі самі знахідки траплялись і в інших святилищах Деметри. Щодо боспорських знахідок світильників, окрім Кітея, вони були знайдені в святилищах Німфея, Майської гори, Береговому-4 в шарах V ст. до н.е. і пізніших - IV-III ст. до н.е. [Журавлев 2004, с. 111]. О. А. Завойкін схиляється до 
того, що світильники мали вотивне значення i не використовувались за прямим призначенням, а були лише символом світла [Журавлев 2004, с. 112].

Цікавий матеріал дають розкопки сакрального комплексу поселення на мисі Зюк. На думку деяких вчених, це Зенонов Херсонес, згаданий Клавдієм Птолемеєм. Серед найцікавіших знахідок слід згадати напис на амфорі $\mathrm{V}$ ст. до н.е., мова в якому йшла про якісь внески зерном. Такі первинки врожаю збиралися для внеску до храму божества [Масленников 2007, с. 339]. Появу такої традиції можна пов'язати з посиленням контактів 3 Афінами, де був видано декрет про пожертви зерна в Елевсін.

Про те, що даний сакральний комплекс є пов'язаним 3 Деметрою, свідчать знайдені теракоти, одна $з$ яких представляє Деметру у скорботі [Масленников 2007, с. 346-347]. Крім того, тут були знайдені графіті з буквами АП, які можна трактувати як посвяти Аполлону. А первинки також приносили в храм Аполлона [Масленников 2007, с. 349-350]. Через це конкретизація сакрального значення даного комплексу ускладнюється.

Теракоти Деметри та Кори-Персефони трапляються не лише при розкопках городищ, але й некрополів. Так, при розкопках грунтових могил, курганів Пантікапея, Фанагорії та інших боспорських міст були знайдені протоми та статуетки богині VI-V ст. до н.е. [Кобылина 1961, с. 31]. У деяких з них можна побачити в руках плід граната, що дозволяє їх ідентифікувати як Кору-Персефону. Досить часто трапляється фігурка Кори-Персефони, що стоїть та тримає в руці квітку. Прикладом такої може слугувати пантикапейська статуетка дівчини 3 вінком. Її̈ було знайдено при розкопках некрополя. На голові у Кори калаф, одягнена вона у хітон з рукавами та гіматій із прямими короткими складками попереду. Опущеною рукою вона притримує одяг. Волосся горизонтальними хвилями падають на плечі. На нижній частині одягу є залишки червоної фарби [Силантьева 1974, с. 16, табл. 3, 1; Передольская 1962, с. 52; Сапрыкин 1983, с. 62]. Цей сюжет, як і у теракоти з Гермонаси, пов'язано з міфом про Деметру. Наявність у руці богині квітки дозволяє віднести іiі до КориПерсефони, яка збирала квіти в момент викрадення.

Знахідки теракот елевсінських богинь при розкопках некрополя цікаві не тільки як свідчення сімейних культів та особливостей поховального обряду, а також демонструють рідкісні іконографічні типи. Так, нетиповою для Боспору є протома Деметри в короні, яка прикрашена плодами. У руці богиня тримає яблуко. У вухах - сережки, на руках - браслети. Походить вона 3 гробниці поблизу Феодосії. Поряд з нею була знайдена статуетка актораГеракла і двох жінок [Кобылина 1974, с. 79]. Можна припустити, що статуетки жінок зображають учасників елевсінських містерії. Аналоги таких статуеток знаходили як на материковій Греції, так і при розкопках поселень Боспору [Higgins 1954, p. 873 874].

Окремо хотілося б відзначити парну статуетку Деметри з маленькою Корою на плечі, що походить 3 дитячого поховання на горі Мітрідат (Пантикапей) Одягнені вони в хітони та гіматії, які закривають ноги. У Деметри пряме коротке волосся, у Кори на голові калаф, волосся локонами спускається на плечі. База прямокутна. Порожниста, знизу відкрита. Виготовлена у формі з двох половинок, на зворотній гладкій стороні прямокутний отвір. Біле облицювання, на волоссі обох фігур червоно-коричнева фарба. [Силантьева 1974, с. 17, табл. 5, 3; ОАК 1876, табл. VI, 1]. Зображення Кори маленькою може бути пов'язане 3 уявленнями еллінами Кори, як молодих сходів, а Деметри, як зрілого колосся, що годує людей і надає життя новому врожаю [Томпсон 1958, с. 230, Русяева 1975, с. 52].

Цікавим є набір статуеток з одного пантікапейського поховання: богиня на троні та бог, який лежить. В теракоті бога можна побачити Аїда, чоловіка Персефони, або хтонічного Діоніса, який був тісно пов'язаний з елевсінськими містеріями. В цьому випадку С.Ю. Саприкін вважає, що богиню на троні можна трактувати як Кору-Персефону [Сапрыкин 1983, с. 63] Аналогічна теракота є в Німфейському святилищі. При розкопках східного некрополю Фанагорії знайдено парну статуетку богинь Деметри та Кори [Завойкин 2003, с. 106].

Хоча теракот у могилах знайдено небагато, їх наявність змушує проаналізувати це явище. Факт знахідок теракот у могилах може свідчити про хтонічний, а також катохтонічний 
характер культу богині родючості. Елліни пов'язували свої уявлення про життя і смерть 3 зерном, яке кидали у землю. А.А. Передольська пов'язує теракоти в могилах 3 нормою їх присутності серед поховального інвентаря [Передольская 1955, с. 54]. Щодо культового призначення цих статуеток і протом, то дослідниця відносить їх до Кори-Персефони, богині підземного світу, яка повернулась на землю, тобто подала смерть [Скуднова 1970, с. 84; Русяева 1975, с. 53]. Такої ж думки дотримуються А.С. Русяєва і Т.М. Шевченко. Так, богиня землеробства уособлювала в собі віру у щасливе потойбічне життя. Якщо Кора-Персефона померла і воскресла, то Деметра зникла і повернулась на Олімп, тобто обидві богині несли в собі ідею повернення, воскресіння, щасливого життя після смерті [Русяева 1975, с. 59].

Цікавою є думка Т.М. Шевченко щодо причини наявності в некрополях статуеток і протом Деметри та Кори. На матеріалах Херсонесу вона робить припущення, що теракоти в могили клали учасникам елевсінських містерії. Присутність теракот у дитячих похованнях також свідчить на користь цього твердження, адже іноді дітей посвячували у містерії. Отже, теракоти були знаком того, що поховані з ними люди мали знання про містерії та особливий статус у потойбічному світі [Шевченко 2008, с. 211-214].

«Счастливы те из людей земнородных, кто таинство видел.

Тот же, кто им непричастен, по смерти не будет вовеки

Доли подобной иметь в многосумрачном царстве подземном»

(Hom. Hymn. V 480-482).

Таке твердження має свій сенс. Як у Херсонесі, так і на Боспорі, поховання з виробами коропластів у складі інвентарю $є$ дуже рідкісними. В переважній більшості це поховання жінок і дітей. Але чи були небіжчики посвяченими у містерії, чи ні, сказати важко.

Слід також згадати гіпотезу В.Н. Корпусової, яка теж має свій сенс. Вона проводить аналогії з магією, тобто покладенням амулетів до могил, особливо до дитячих, 3 метою захисту небіжчика у потойбічному світі. 3 огляду на те, що найчастіше теракоти знаходять у дитячих і жіночих похованнях, дослідниця припускає, що зображення богині несли функцію своєрідних амулетів [Корпусова 1983, с. 80]. Люди вірили, що Деметра або Кора-Персефона стане заступницею небіжчика і допоможе дістатися щасливого потойбічного життя.

Висновки. Період VI-початку V ст. до н.е. характеризується проникненням i розповсюдженням культу Деметри на Боспорі. Традиції та уявлення, що пов'язані з культом Деметри, були принесені на Боспор грецькими колоністами. Знахідки теракотових статуеток богині родючості та їі дочки у боспорських будинках та домашніх святилищах початку VI ст. до н.е. свідчить про популярність культу Деметри серед колоністів. Шанування богині родючості простежується не лише серед культів родинного кола. Ще у першій половині VI ст. до н.е. виникає велике громадське святилище на їі честь у Німфеї, а на межі VI - V ст. до н.е. - у Мірмекії, поблизу Фанагорії та на Фонталовому півострові.

Таке швидке розповсюдження культу Деметри зумовлене землеробським характером новостворених поселень, а також значним місцем Деметри у пантеоні богів Мілету метрополії Боспору. Але якщо простежити коріння культу Деметри в Мілеті, то стає зрозумілим, що деякі його елементи йдуть з Аттики, де, як відомо, знаходився головний сакральний комплекс богині землеробства і проводились свята на честь Деметри та їі дочки Елевсінські містерії. Елевсін став загальногрецьким центром землеробських культів із якого по всьому античному світу поширювався культ Деметри Елевсінської. Його елементи можна простежити і в боспорській релігії.

Хтонічну іпостась богині репрезентують сакральні комплекси Майська гора і Берегове4. Місце, яке було обране для будівництва, вказує на шанування тут Деметри та КориПерсефони у їх хтонічній іпостасі, адже природні розщелини та грязьові вулкани розглядалися давніми греками як входи до підземного світу та мали ритуальне значення. Подібне розташування святилищ Деметри відоме й на материковій Греції, а також в Елевсіні. 3 аналізу знахідок та самого комплексу можна зробити висновок про шанування тут Елевсінських богинь. 
3 приходом до влади династії Спартокідів посилюється вплив Афін на Боспорську державу. Відтоді до нас надійшло письмове свідоцтво про зв'язок Боспору з Елевсіном. У другій половині V ст. до н.е. засновуються нові громадські святилища у Пантікапеї, Кітеї та Феодосії, де також простежуються риси елевсінського культу.

У більшості випадків основним джерелом, що дозволяє інтерпретувати знайдені громадські та родинні святилища, стають теракоти Деметри та її дочки, що були знайдені у значній кількості при розкопках міст і сільських поселень Боспору. Більшість 3 них $\epsilon$ імпортними, найбільше - родоських статуеток. Для всіх теракот того часу є характерними архаїчні риси: монументальна поза, широко відкриті очі, так звана архаїчна посмішка. Від V ст. до н.е. серед привізних теракот з'являються аттичні, які, на відміну від родоських, мають класичні, а не архаїчні риси. Власне боспорські глиняні вироби зберігають архаїчні риси, наслідують родоські та іонічні образи.

Катохтонічні функції Деметри та іiі дочки простежується у поховальному обряді. Теракоти елевсінських богинь знаходять у дитячих і жіночих могилах. Скоріш за все, вони пов'язані з віруваннями у щасливе потойбічне життя і подолання смерті. У грецькій релігії одним із втілень цих вірувань став гомерівський міф про Кору-Персефону, що повернулась 3 підземного світу на землю. Крім того, теракоти могли виконувати функцію оберегів або вказували на причетність небіжчика до Елевсінських містерій. Відсутність чітких свідчень щодо статуеток Деметри та Кори у поховальному інвентарі не дає можливість точно визначитись в цьому питанні.

Отже, аналіз пам'яток раннього Боспору не дає можливості стверджувати, що культ Деметри входив до числа державних культів. Проте вони засвідчують безумовну популярність богині у іï землеробсько-хтоничній іпостасі серед громадськості окремих полісів і в родинних культах.

Вахрамеева А.В.

\section{КУЛЬТ ДЕМЕТРЫ В ОТДЕЛЬНЫХ ГОРОДАХ И ПОСЕЛЕНИЯХ БОСПОРА В АРХАИЧЕСКИЙ ПЕРИОД}

В статье рассмотрен культ Деметры на Боспоре в VI-V вв. до н.э. В этот период были основаны основные боспорские святилища в честь богини земледелия. Раскопки городов и поселений Боспора дают материалы, подтверждающие почитание Деметры как в семейном кругу, так и вхождение ее в пантеон полиса. К крупным сакральным комплексам, посвященным Деметре, относились: Нимфейское святилище, Береговое-4 и Майская гора. Большое влияние на боспорский культ богини плодородия оказывали элевсинские традиции. Терракоты Деметры и Коры находят при раскопках как поселений, так и некрополей. Большая часть из них относится к типу «богиня на троне». Для статуэток и протом Деметры и Коры-Персефоны VI-V вв. до н.э. характерен родосско-ионический стиль. Находки статуэток в некрополе и расщелинах на территории темносов говорит о почитание хтонической ипостаси богини, вместе с земледельческой. Кроме того, о популярности богини плодородия на Боспоре свидетельствуют граффити, посвященные Деметре. Такое быстрое распространение культа Деметры обусловлено земледельческим характером экономики Боспора. Приоритет античных норм и традиций в культе Деметры сохранялся в течение указанного периода.

Ключевые слова: Деметра, Кора-Персефона, VI-V в. до н.э., Боспор, сакральная жизнь, святилище, терракоты, эпиграфические источники, элевсинский культ, земледельческо-хтонический характер культа

Vakhrameieva G. $V$.

\section{THE CULT OF DEMETER IN CITIES AND SETTLEMENTS OF THE BOSPORUS IN THE ARCHAIC PERIOD}

The article is devoted to the general characteristics of Demeter cult in the Bosporus, VI- V centuries BC. The author gives account of the main Bosporus sanctuaries of Demeter. Archeological found in cities and settlements of the Bosporus gives us material that confirmed that cult of Demeter keeps its place in 
families and in polices pantheon as well. The great sanctuaries of Demeter on Bosporus were the Nymphaion sanctuary, Beregovoe-4 and Mayskaya Gora. Great influence also had an Eleusinian tradition. Terracotta figures was founded during excavation in settlements and necropolis. Most terracotta can be attributed to the type of «goddess on the throne». Figurines and protomes of Demeter and Cores-Persephone VI-V centuries $\mathrm{BC}$ refers to the Rhodes-Ionic style. Founding these figures in the necropolis and pits on the territory of sanctuary could be an evidence of praying for chthonic and agricultural icons of goddess as well. Apart from sacral complexes and coroplast products, epigraphic sources, graffiti. Growing influence of Demeter cult in such short terms was the result of agricultural economy. The priority of ancient rules and traditions in the cult of Demeter was maintained in the course of this period.

Keywords: Demeter, Kore-Persephone, VI - V centuries BC, the Bosporus, sacred life, sanctuary, terracotta, epigraphic sources, the Eleusinian cult, agricultural and chthonic character of the cult.

\section{СПИСОК ДЖЕРЕЛ I ЛІТЕРАТУРИ}

Античная мифология / Под ред. А. Лактионова. - М.: МИДГАРД, 2004. - 768 с.

Блаватский В.Д. Отчет о раскопках Пантикапея в 1945-1949, 1952 и 1953 гг. / В.Д. Блаватский // Пантикапей. - М.: Изд-во АН СССР, 1962. - С. 6-85.

Бунин Д.С. Культ Афродиты на Боспоре (VI в. до н.э. - III в. н.э.): автореф. дис. ... канд. истор. наук: спец. 07.00.03. / Д.С. Бунин. - М., 2005. -28 с.

Бутягин А.М. Пять лет работ Мирмекийской экспедиции / А.М. Бутягин // Материалы V Боспорских чтений. - Керчь, 2004. - С. 48-54.

Вахтина М.Ю. Терракотовые статуэтки из раскопок Порфмия / М.Ю. Вахтина // Боспорские исследования. - Вып. ХХІІІ. - Симферополь, 2010. - С. 233-250.

Гайдукевич В.Ф. Раскопки Илурата, Тиритаки и Мирмекия / В.Ф. Гайдукевич // КСИИМК. 1952. - Т. 45. - С. 97-113.

Гайдукевич В.Ф. Раскопки Мирмекия и Тиритаки, археологические разведки на Керченском полуострове в 1937-1939 гг. / В.Ф. Гайдукевич // ВДИ. - 1940. - № 3-4. - С. 300-317.

Горская О.В. Культы Нимфея по материалам граффити / О.В. Горская // Боспорский феномен: Погребальные памятники и святилища: материалы международной науч. конф. - Ч. І. - СПб., 2002. C. 114-121.

Денисова В.И. Коропластика Боспора. / В.И. Денисова. - Л.: Наука, 1981. - 171 с.

Долгоруков В.С. Фанагория / В.С. Долгоруков // Археология СССР: в 20 т. Античные государства Северного Причерноморья. - М.: Наука, 1984. - С. 77-80.

Журавлева Д.В. Свет и светильники в элевсинских таинства (по материалам святилища «Береговой-4») / Д.В. Журавлева, А.А. Завойкин // Боспорский феномен. - СПб., 2004. - С. 106-118.

Завойкин А.А. $\Theta \Theta €$ : двойственность и троичность на святилище элевсинских богинь («Береговое-4») / А.А. Завойкин // Древности Боспора. - 2003. - Т. 6. - С. 104-119

Завойкин А.А. Святилище Деметры и Коры на Фонталовском полуострове: природная среда и сакральная топография / А.А. Завойкин // ВДИ. - 2006. - № 3. - С.61-76.

Завойкин А.A. T $\Omega$ TE $\Omega$ : образы и символы Матери и Дочери в святилище элевсинских богинь на «Береговом 4»/ А.А. Завойкин // Боспорский феномен: Погребальные памятники и святилища: материалы международной науч. конф. - Ч. І. - СПб, 2002. - С. 259-266.

Зинько В.Н. Сакральные памятники VI-I вв. до н. э. европейского побережья Боспора Киммерийского / В.Н. Зинько // Древности Боспора. - 2008. - Т. 12. - Ч. 1. - С. 250-257.

Зинько В.Н. Хора городов европейского побережья Боспора Киммерийского (VI-I вв. до н.э.) / В.Н. Зинько // Боспорские исследования. - 2007. - Вып. XV. - 336 с.

Ильина Т.А. Проблемы исследования античной коропластики Боспора: опыт комплексного анализа материалов святилища на Майской горе близь Фанагории: дис. ... канд. ист. наук: спец. 07.00.06 «Археология» / Т.А. Ильина. - М., 2008 - 220 с.

Кобылина М.М. Фанагория / М.М. Кобылина // МИА. - 1956. - № 57. - С. 5-101.

Кобылина М.М. Мастерская пантикапейских коропластов / М.М. Кобылина // САИ / отв. ред. М. М. Кобылина. - Вып. Г1-11. - Ч. 3. - М.: Наука, 1974. - С.47-53.

Кобылина М.М. Терракотовые статуэтки Пантикапея и Фанагории / М.М. Кобылина. - М.: Изд-во АН СССР,1961. - 182 с. 
Кобылина М.М. Терракотовые статуэтки Семибратнего городища / М.М. Кобылина // САИ / отв. ред. М.М. Кобылина. - Вып. Г1-11. - Ч. 4. - М.: Наука, 1974а. - С. $42-43$.

Кобылина М.М. Терракотовые статуэтки Фанагории / М.М. Кобылина // САИ / отв. ред. М.М. Кобылина. - Вып. Г1-11. - Ч. 4. - М.: Наука, 1974б. - С. 20-30.

Коровина А.К. Терракотовые статуэтки Гермонассы / А.К. Коровина // САИ / отв. ред. М.М. Кобылина. - Вып. Г1-11. - Ч. 4. - М.: Наука, 1974. - С. 39-40.

Корпусова В.Н. Некрополь Золотое (К этнокультурной истории европейского Боспора) / В.Н. Корпусова. - К.: Наук. думка, 1983. - 182 с.

Кругликова И.Т. Статуэтки из Киммерика / И.Т. Кругликова // САИ / отв. ред. М.М. Кобылина. - Вып. Г1-11. - Ч.1-2. - М.: Наука, 1970. - С. 82-83.

Кругликова И.Т. Сельское хозяйство Боспора / И.Т. Кругликова. - М.: Наука, 1975. - 300 с.

Кузьмина Ю.Н. Эллинские святилища Боспора в VI-I вв. до н.э. (по материалам раскопок сакральных комплексов Азиатского Боспора): автореф. дис. ... канд. ист. наук: спец. 07.00.06 «Археология» / Ю.Н. Кузьмина. - М., 2011. - 22 с.

Марченко И.Д. Терракоты из святилища на Майской горе (Блеваке) / И.Д. Марченко // САИ / отв. ред. М.М. Кобылина. - Вып. Г1-11. - Ч. 4. - М.: Наука, 1974. - С. 31-35.

Масленников А.А. Сельские святилища Европейского Боспора / А.А. Маслеников. - Тула: Гриф и К., 2007. - 564 с.

Молев Е.А. Раскопки городища Китея / Е.А. Молев, Н.А. Сон // АДУ 2009 р. - К.: ІА НАНУ, 2010. - C. 292-293.

Молев Е.А. Терракотовые статуэтки из Китейского святилища / Е.А. Молев, Н.В. Молева // Боспорские исследования. -2003. - Вып. III. - С. 252-263.

Молева Н.В. Обряд жертвоприношений в Китейском святилище/ Н.В. Молева // Очерки сакральной жизни Боспора. Избранные статьи. - Н. Новгород: Изд-во Нижнегородского ун-та, 2002. C. 70-74.

Молева Н. В. Сакральные памятники Боспора VI - начала V в. до н.э. / Н.В. Молева // Боспорский феномен: Колонизация региона. Формирование полисов. Образование государства: Материалы международной науч. конф. - Ч. І. - СПб, 2001.- С. 131-133.

Наливкина М.А. Терракоты Мирмекия и Тиритаки: из раскопок 1933-1940 гг. / М.А. Наливкина // МИА. - 1952. - № 25 - С. 327-347.

Отчет императорской археологической комиссии за 1862. - СПб.: Тип. Императорской академии наук, 1876. - $176 \mathrm{c.}$

Передольская А.А. Терракоты из кургана Большая Близница и гомеровский гимн Деметре / А.А. Передольская // Труды Государственного Эрмитажа. - 1962. - Т. VII. - C. 46-91.

Передольская А.А. К вопросу о терракотах из кургана Большая Близница / А.А. Передольская // CA. - 1955. - № XXIV. - C. 54-73.

Петрова Э.Б. О культах античной Феодосии / Э.Б. Петрова // Боспорские исследования. -2001. - Вып. І. - С. 233-239.

Русяева А.C. Античные терракоты Северо-Западного Причерноморья (VI-I вв. до н.э.) / А.С. Русяева- К.: Наук. думка, 1982. - 172 с.

Русяева А.С. Земледельческие культы в Ольвии догетского времени. / А.С. Русяева. - К.: Наук. думка, 1979. - $172 \mathrm{c}$.

Русяева А.С. Деметра Боспорская / А.С. Русяева // Склеп Деметры: Памятники археологии Керченского историко- культурного заповедника [Е.А. Зинько, А.С. Русяева, Е.А. Савостина и др.]. К.: Мистецтво, 2009. - С. 102-150.

Русяева А.С. Земледельческие культы Ольвии догетского времени: дис. ... канд.. истор. наук / А.С. Русяева: спец. 07.00 .06 «Археология». - К., 1975. - 272 с.

Русяева А.С. Духовная культура населения Ольвийского государства: дис. ... докт. ист. наук: спец. 07.00 .06 «Археология» / А.С. Русяева. - К., 1990 - 393 с.

Русяева А.С. Религия понтийских эллинов в античную эпоху: Мифы. Святилища. Культы олимпийских богов и героев / А.С. Русяева. - К.: Стилос, 2005. - 559 с.

Сапрыкин С.Ю. Культ Деметры в Боспорском царстве в VI-IV вв. до н. э. / С.Ю. Сапрыкин // Из истории античного общества. - Горький, 1983. - С. 59-72.

Силантьева П.Ф. Терракоты Пантикапея / П.Ф. Силантьева // САИ / отв. ред. М.М. Кобылина. - Вып. Г1-11, ч. 3. - М.: Наука, 1974. - С. 5-37. 
Скржинская М.В. Древнегреческие праздники в Элладе и Северном Причерноморье / М.В. Скржинская. - К.: Ин-т истории Украины НАН Украины, 2009. - 360 с.

Скржинская М.В. Основные черты древнегреческих праздников и их отражение в боспорских археологических находках / М.В. Скржинская // Боспорские исследования. - 2004. - Вып. V. - С. 90-108.

Скуднова В.М. Терракоты из Нимфея / В.М. Скуднова // САИ / отв. ред. М. М. Кобылина. Вып. Г1-11. - Ч.1-2. - М.: Наука, 1970. - С. 83-89.

Соколова О.Ю. Нимфей / О.Ю. Соколова // Античные памятники Крыма. - К.: Мистецтво, 2004. - С. 89-134. [Электронный ресурс]. - Режим доступа:

http://bosportemple.ru/content/library/paper_06.htm.

Томсон Дж. Исследования по истории древнегреческого общества / Дж. Томпсон / пер. с англ. М.Б. Гракова-Свиридова, В.С. Соколова. - М.: Изд-во иностр. лит., 1958. - 659 с.

Крижицький С.Д. Античні держави Північного Причорномор'я / С.Д. Крижицький, В.М. Зубар, А.С. Русяєва [Україна крізь віки. - Т. 2.]. - К.: Альтернативи, 1998. - 351 с.

Чевелев О.Д. Новые исследования в Анапском районе Краснодарского края / О.Д. Чевелев, С.В. Кашаев, Н.И. Сударев // Боспорские чтения. - 2011. - Вып. 12. - С. 403-411.

Чистов Д.Е. "Святилище Деметры" и восточные кварталы Мирмекия в IV в. до н.э. / Д.Е. Чистов // Боспорские исследования. - 2006. - Вып. 13. - С. 99-133.

Чистов Д.Е. Святилище Деметры в Мирмекии: попытка реконструкции комплекса / Д.Е. Чистов // Боспорский феномен: проблемы хронологии и датировки памятников. - СПб., 2004. C. 131-142.

Шауб И.Ю. Миф, культ, ритуал в Северном Причерноморье (VII-IV вв. до н.э.) / И.Ю. Шауб. СПб.: Издательство С-Петерб. ун-та; Филологический факультет СПбГУ, 2007. - 484 с.

Шевченко Т.М. Особливості релігійного світогляду населення античного Херсонеса: дис. ... канд.. істор. наук: спец. 07.00 .04 «Археологія» / Т.М. Шевченко. - К., 2008 - 392 с.

Пругло В.И. Терракоты из Тиритаки / В.И. Пругло // Свод археологических источников / отв. ред. М. М. Кобылина. - Вып. Г1-11. - Ч.1-2. - М.: Наука, 1970. - С. 90-94.

Higgins R.A. Catalogue of the terracottas in the department of Greek and Roman antiquities British Museum / R.A. Higgins. - London, 1954. -432 p.

Merker G.S. The Sanctuary of Demeter and Kore: Terracotta Figurines of the Classical, Hellenistic and Roman Periods / G.S. Merker. - New Jersey; Princeton: The American School of Classical Studies at Athens, 2000. $-346 \mathrm{p}$.

Ohlerich I. Kultorte und Heiligtümer auf dem Gebiet des Bosporanischen Reiches: Dissertation Dr. phil / I. Ohlerich . - Rostock, 2011. - 512 s.

Winter F. Die Typen der figurlichen Terrekoten / F. Winter. - Berlin; Stuttgart, 1903. - 480 p.

\section{REFERENCES}

Antichnaya mifologiya / Pod red. A. Laktionova. - M.: MIDGARD, 2004. - 768 s.

Blavatskij V.D. Otchet o raskopkah Pantikapeya v 1945-1949, 1952 i 1953 gg. / V.D. Blavatskij // Pantikapej. - M.: Izd-vo AN SSSR, 1962. - S. 6-85.

Bunin D.S. Kult Afrodity na Bospore (VI v. do n.e. - III v. n.e.): avtoref. dis. ... kand. istor. nauk: 07. 00. 03. / D.S. Bunin. - M., 2005. -28 s.

Butyagin A.M. Pyat let rabot Mirmekijskoj ekspedicii / A.M. Butyagin // Materialy V Bosporskih chtenij - Kerch, 2004. - S. 48-54.

Vahtina M.Yu. Terrakotovye statuetki iz raskopok Porfmiya / M.Yu. Vahtina // Bosporskie issledovaniya. - Simferopol, 2010. - Vyp. XXIII. - S. 233-250.

Gajdukevich V.F. Raskopki Ilurata, Tiritaki i Mirmekiya / V.F. Gajdukevich // KSIIMK. - 1952. - T. 45. - S. 97-113.

Gajdukevich V.F. Raskopki Mirmekiya i Tiritaki, arheologicheskie razvedki na Kerchenskom poluostrove v 1937-1939 gg. / V.F. Gajdukevich // VDI. - 1940. - № 3-4. - S. 300-317.

Gorskaya O.V. Kulty Nimfeya po materialam graffiti / O.V. Gorskaya // Bosporskij fenomen: Pogrebalnye pamyatniki i svyatilisha: Materialy mezhdunarodnoj nauch. konf. - Ch. I. - SPb., 2002. - S. 114-121.

Denisova V.I. Koroplastika Bospora. / V.I. Denisova. - L.: Nauka, 1981. - 171 s.

Dolgorukov V.S. Fanagoriya / V.S. Dolgorukov // Antichnye gosudarstva Severnogo Prichernomorya. - M.: Nauka, 1984. - S. 77-80. 
Zhuravleva D.V. Svet i svetilniki v elevsinskih tainstva (po materialam svyatilisha «Beregovoj-4»)/ D.V. Zhuravleva, A.A. Zavojkin // Bosporskij fenomen. - SPb., 2004. - S. 106-118.

Zavojkin A.A. $\Theta \Theta \epsilon$ : dvojstvennost i troichnost na svyatilishe elevsinskih bogin («Beregovoe-4») / A.A. Zavojkin // Drevnosti Bospora. - 2003. - T. 6. - S. 104-119

Zavojkin A.A. Svyatilishe Demetry i Kory na Fontalovskom poluostrove: prirodnaya sreda i sakralnaya topografiya / A.A. Zavojkin // Vestnik drevnej istorii. - 2006. - № 3. - S.61-76.

Zavojkin A.A. T $\Omega$ TE $\Omega$ : obrazy i simvoly Materi i Docheri v svyatilishe elevsinskih bogin na «Beregovom 4»/ A.A. Zavojkin // Bosporskij fenomen: Pogrebalnye pamyatniki i svyatilisha: Materialy mezhdunarodnoj nauch. konf. - Ch. I. - SPb, 2002. - S. 259-266.

Zinko V.N. Sakralnye pamyatniki VI-I vv. do n. e. evropejskogo poberezhya Bospora Kimmerijskogo / V.N. Zinko // Drevnosti Bospora. - 2008. - T. 12. - Ch. 1. - S. 250-257.

Zinko V.N. Hora gorodov evropejskogo poberezhya Bospora Kimmerijskogo (VI-I vv. do n.e.) / V.N. Zinko // Bosporskie issledovaniya. - 2007. - Vyp. XV. - $336 \mathrm{~s}$.

Ilina T.A. Problemy issledovaniya antichnoj koroplastiki Bospora: opyt kompleksnogo analiza materialov svyatilisha na Majskoj gore bliz Fanagorii: dis. ... kand. ist. nauk: spec. 07.00.06 «Arheologiya» / T.A. Ilina. - M., $2008-220$ s.

Kobylina M.M. Fanagoriya / M.M. Kobylina // MIA. - 1956. - № 57. - S. 5-101.

Kobylina M.M. Masterskaya pantikapejskih koroplastov / M.M. Kobylina // SAI / otv. red. M.M. Kobylina. - Vyp. G1-11. - Ch. 3. - M.: Nauka, 1974. - S.47-53.

Kobylina M.M. Terrakotovye statuetki Pantikapeya i Fanagorii / M.M. Kobylina. - M.: Izd-vo AN SSSR,1961. - $182 \mathrm{~s}$.

Kobylina M.M. Terrakotovye statuetki Semibratnego gorodisha / M.M. Kobylina // SAI / otv. red. M.M. Kobylina. - Vyp. G1-11. - Ch. 4. - M.: Nauka, 1974a. - S. 42-43.

Kobylina M.M. Terrakotovye statuetki Fanagorii / M.M. Kobylina // SAI / otv. red. M.M. Kobylina. Vyp. G1-11. - Ch. 4. - M.: Nauka, 1974b. - S. 20-30.

Korovina A.K. Terrakotovye statuetki Germonassy / A.K. Korovina // SAI / otv. red. M.M Kobylina. - Vyp. G1-11. - Ch. 4. - M.: Nauka, 1974. - S. 39-40.

Korpusova V.N. Nekropol Zolotoe (K etnokulturnoj istorii evropejskogo Bospora) / V.N. Korpusova. - K.: Nauk. dumka, 1983. $-182 \mathrm{~s}$.

Kruglikova I.T. Statuetki iz Kimmerika / I.T. Kruglikova // SAI / otv. red. M.M. Kobylina. - Vyp. G1-11. - Ch.1-2. - M.: Nauka, 1970. - S. 82-83.

Kruglikova I.T. Selskoe hozyajstvo Bospora / I.T. Kruglikova. - M.: Nauka, 1975. - 300 s.

Kuzmina Yu.N. Ellinskie svyatilisha Bospora v VI-I vv. do n.e. (po materialam raskopok sakralnyh kompleksov Aziatskogo Bospora): avtoref. dis. ... kand. ist. nauk 07.00.06 «Arheologiya» / Yu.N. Kuzmina. - M., 2011. $-22 \mathrm{~s}$.

Marchenko I.D. Terrakoty iz svyatilisha na Majskoj gore (Blevake) / I.D. Marchenko // SAI / otv. red. M.M. Kobylina. - Vyp. G1-11. - Ch. 4. - M.: Nauka, 1974. - S. 31-35.

Maslennikov A.A. Selskie svyatilisha Evropejskogo Bospora / A.A. Maslenikov. - Tula: Grif i K., 2007. $-564 \mathrm{~s}$.

Molev E.A. Raskopki gorodisha Kiteya / E.A. Molev, N.A. Son // ADU 2009 r. - K.: IA NANU, 2010. - S. 292-293.

Molev E.A. Terrakotovye statuetki iz Kitejskogo svyatilisha / E.A. Molev, N.V. Moleva // Bosporskie issledovaniya. -2003. - Vyp. III. - S. 252-263.

Moleva N.V. Obryad zhertvoprinoshenij v Kitejskom svyatilishe/ N.V. Moleva // Ocherki sakralnoj zhizni Bospora. Izbrannye stati. - N. Novgorod: Izd-vo Nizhnegorodskogo un-ta, 2002. - S. 70-74.

Moleva N.V. Sakralnye pamyatniki Bospora VI - nachala V v. do n.e. / N.V. Moleva // Bosporskij fenomen: Kolonizaciya regiona. Formirovanie polisov. Obrazovanie gosudarstva: Materialy mezhdunarodnoj nauch. konf. - Ch. I. - SPb, 2001.- S. 131-133.

Nalivkina M.A. Terrakoty Mirmekiya i Tiritaki: iz raskopok 1933-1940 gg. / M.A. Nalivkina // MIA. - 1952. - № 25 - S. 327-347.

Otchet imperatorskoj arheologicheskoj komissii za 1862. - SPb: Tip. Imperatorskoj akademii nauk, 1876. $-176 \mathrm{~s}$.

Peredolskaya A.A. Terrakoty iz kurgana Bolshaya Bliznica i gomerovskij gimn Demetre / A.A. Peredolskaya // Trudy Gosudarstvennogo Ermitazha. - 1962. - T. VII. - S. 46-91.

Peredolskaya A.A. K voprosu o terrakotah iz kurgana Bolshaya Bliznica / A.A. Peredolskaya // SA. 1955. - № XXIV. - S. 54-73. 
Petrova E.B. O kultah antichnoj Feodosii / E.B. Petrova // Bosporskie issledovaniya. - 2001. - Vyp. I. - S. 233-239.

Rusyaeva A.S. Antichnye terrakoty Severo-Zapadnogo Prichernomorya (VI-I vv. do n.e.) / A.S. Rusyaeva- K.: Nauk. dumka, 1982. -172 s.

Rusyaeva A.S. Zemledelcheskie kulty v Olvii dogetskogo vremeni. / A.S. Rusyaeva. - K.: Nauk. dumka, 1979. - $172 \mathrm{~s}$.

Rusyaeva A.S. Demetra Bosporskaya / A.S. Rusyaeva // Sklep Demetry: Pamyatniki arheologii Kerchenskogo istoriko- kulturnogo zapovednika [E.A. Zinko, A.S. Rusyaeva, E.A. Savostina i dr.]. - K.: Mistectvo, 2009. - S. 102-150.

Rusyaeva A.S. Zemledelcheskie kulty Olvii dogetskogo vremeni: dis. ... kand.. istor. nauk / A.S. Rusyaeva: spec. 07.00 .06 «Arheologiya». - K., 1975. - 272 s.

Rusyaeva A.S. Duhovnaya kultura naseleniya Olvijskogo gosudarstva: dis. ... dokt. ist. nauk: spec. 07.00.06 «Arheologiya» / A.S. Rusyaeva. - K., 1990 - 393 s.

Rusyaeva A.S. Religiya pontijskih ellinov v antichnuyu epohu: Mify. Svyatilisha. Kulty olimpijskih bogov i geroev / A.S. Rusyaeva. - K.: Stilos, 2005. - 559 s.

Saprykin S.Yu. Kult Demetry v Bosporskom carstve v VI-IV vv. do n. e. / S.Yu. Saprykin // Iz istorii antichnogo obshestva. - Gorkij, 1983. - S. 59-72.

Silanteva P.F. Terrakoty Pantikapeya / P.F. Silanteva // SAI / otv. red. M.M. Kobylina. - Vyp. G1-11, ch. 3. - M.: Nauka, 1974. - S. 5-37.

Skrzhinskaya M.V. Drevnegrecheskie prazdniki v Ellade i Severnom Prichernomore / M.V. Skrzhinskaya. - K.: Institut istorii Ukrainy NAN Ukrainy, 2009. - $360 \mathrm{~s}$.

Skrzhinskaya M.V. Osnovnye cherty drevnegrecheskih prazdnikov i ih otrazhenie v bosporskih arheologicheskih nahodkah / M.V. Skrzhinskaya // Bosporskie issledovaniya. - 2004. - Vyp. V. - S. 90-108.

Skudnova V.M. Terrakoty iz Nimfeya / V.M. Skudnova // SAI / otv. red. M.M. Kobylina. - Vyp. G111. - Ch.1-2. - M.: Nauka, 1970. - S. 83-89.

Sokolova O.Yu. Nimfej /O.Yu. Sokolova // Antichnye pamyatniki Kryma. - K.: Mistectvo, 2004. - S. 89-134. [Elektronnyj resurs]. - Rezhim dostupa: http://bosportemple.ru/content/library/paper_06.htm.

Tomson Dzh. Issledovaniya po istorii drevnegrecheskogo obshestva / Dzh. Tompson / per. s angl. M.B. Grakova-Sviridova, V.S. Sokolova. - M.: Izd-vo inostr. lit., 1958. - 659 s.

Krizhickij S.D. Antichni derzhavi Pivnichnogo Prichornomor'ya / S.D. Krizhickij, V.M. Zubar, A.S Rusyaeva [Ukrayina kriz viki. - T. 2.]. - K.: Alternativi, 1998. - $351 \mathrm{~s}$.

Chevelev O.D. Novye issledovaniya v Anapskom rajone Krasnodarskogo kraya / O.D. Chevelev, S.V. Kashaev, N.I. Sudarev // Bosporskie chteniya. - 2011. - Vyp. 12. - S. 403-411.

Chistov D.E. «Svyatilishe Demetry» i vostochnye kvartaly Mirmekiya v IV v. do n.e. / D.E. Chistov // Bosporskie issledovaniya. - 2006. - Vyp. 13. - S. 99-133.

Chistov D.E. Svyatilishe Demetry v Mirmekii: popytka rekonstrukcii kompleksa / D.E. Chistov // Bosporskij fenomen: problemy hronologii i datirovki pamyatnikov. - SPb., 2004. - S. 131-142.

Shaub I.Yu. Mif, kult, ritual v Severnom Prichernomore (VII-IV vv. do n.e.) / I.Yu. Shaub. - SPb.: Izdatelstvo S-Peterb. un-ta; Filologicheskij fakultet SPbGU, 2007. - $484 \mathrm{~s}$.

Shevchenko T.M. Osoblivosti religijnogo svitoglyadu naselennya antichnogo Hersonesa: dis. ... kand.. istor. nauk: spec. 07.00.04 «Arheologiya» / T.M. Shevchenko. - K., $2008-392$ s.

Pruglo V.I. Terrakoty iz Tiritaki / V.I. Pruglo // Svod arheologicheskih istochnikov / otv. red. M.M. Kobylina. - Vyp. G1-11. - Ch.1-2. - M.: Nauka, 1970. - S. 90-94.

Higgins R.A. Catalogue of the terracottas in the department of Greek and Roman antiquities British Museum / R.A. Higgins. - London, 1954. - 432 p.

Merker G.S. The Sanctuary of Demeter and Kore: Terracotta Figurines of the Classical, Hellenistic and Roman Periods / G.S. Merker. - New Jersey; Princeton: The American School of Classical Studies at Athens, 2000. $-346 \mathrm{p}$.

Ohlerich I. Kultorte und Heiligtümer auf dem Gebiet des Bosporanischen Reiches: Dissertation Dr. phil / I. Ohlerich. - Rostock, 2011. - 512 s.

Winter F. Die Typen der figurlichen Terrekoten / F. Winter. - Berlin; Stuttgart, 1903. - 480 p. 